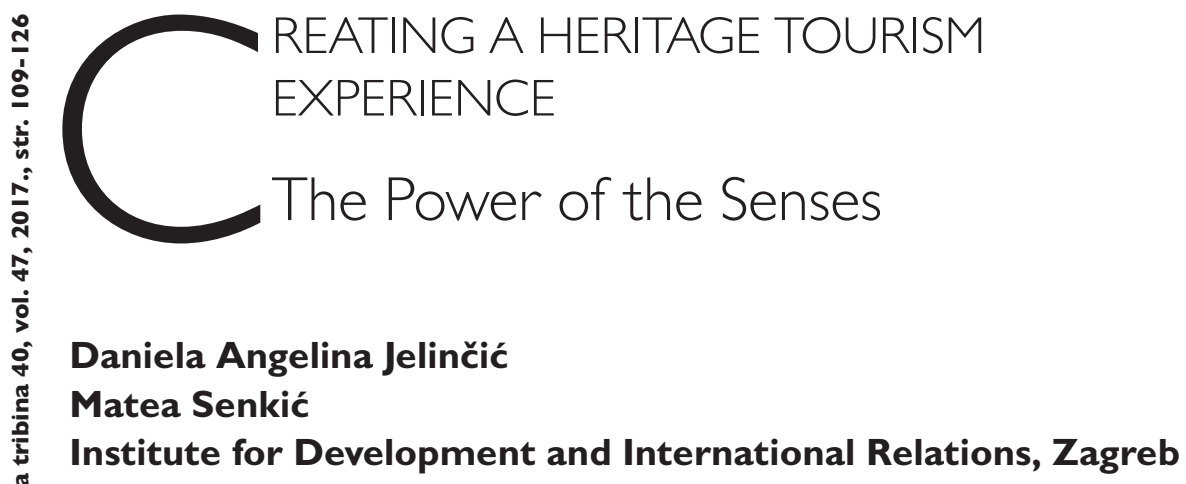

This article discusses the conditions required for meaningful and memorable tourist experiences to occur and for increasing the competitiveness of heritage tourism projects. The aim of this article is to examine whether the theoretical principles of experience creation (the principles of Pine and Gilmore, Timothy and Boyd, Tilden and Schouten) apply to the chosen three case studies (Museum of Broken Relationships, Zagreb; Krapina Neanderthal Museum; and Batana Eco-Museum, Rovinj), drawing on recent developments in creative tourism and the use of cultural/creative industries. The principles of the experience economy are related to heritage tourism so as to showcase its successful use in contemporary heritage displays.

Keywords: heritage tourism, creative tourism, cultural/creative industries, experience creation, memorable experiences, Croatia

It is estimated that cultural tourism today accounts for a market worth around 800 billion - 1.1 trillion USD globally, which is why many places have become tourist destinations. Heritage tourism constitutes a large share of cultural tourism since it represents a distinctive identity relating to a certain location. Its potential has been confirmed in the ever growing number of world heritage sites being added to the UNESCO List. Nevertheless, local/regional/national heritage is not always attractive neither to tourists nor to its bearers, since a large number of heritage sites have begun to resemble one another. In order to make them more attractive and easily associated in the minds of contemporary consumers, cultural tourism strategies have started to focus on creative solutions as a means of heritage (re)creation. The key tool in creating a destination experience is the experience economy. It often includes contemporary expressions of heritage either through the cultural/creative industries or creative tourism projects which have the power to engage with tourists' senses. The senses are the key tool used in experience creation since they have the power to engage with tourists' emotions. Successful heritage attractions stir emotions, which is the last step in the process of experience creation. The scope of this article, however, does not deal with emotions but with the application of theoretical principles relating to experience creation in the three chosen case studies. The importance of 
emotions, however, has been underlined as a subject for further research (for example, see: Jelinčić 2017; Fredrickson 2000; Holyfield 1999).

This article describes the theoretical and statistical background to heritage tourism, and offers background details regarding creative tourism and the use of the cultural/creative industries with respect to consumption in tourism. It further focuses on the concept of the experience economy which is key to successful touristic projects. It is complemented with several innovative Croatian case study examples based on different types of heritage (re)creation. The relevance of senses in experience creation for the successful and sustainable consolidation of the heritage and tourism industry is also discussed.

\section{Heritage tourism}

Tourism is one of the largest and fastest growing industries in the world. According to the United Nations World Tourism Organization (UNWTO 2016), international tourist arrivals have increased from 25 million globally in 1950 to 1186 million in 2015. Likewise, income from international tourism earned by destinations across the globe have surged from 2 billion USD in 1950 to 1260 billion USD in 2015. Europe was the fastest growing region in absolute terms, with 27 million more tourists than in 2014. According to the UNWTO's long-term forecast report named Tourism Towards 2030, international tourist arrivals worldwide are expected to increase by $3.3 \%$ a year between 2010 and 2030 , reaching a remarkable 1.8 billion by 2030 (UNWTO 2015a).

Today, culture presents a key resource upon which travel draws, and "it is safe to assume that a majority of tourist attractions and destinations in the world today are based on elements of cultural heritage" (Timothy 2011: 3). In fact, cultural tourism has recently become one of the fastest growing trends in tourism. The European Commission (2017) estimates that "cultural tourism accounts for $40 \%$ of all European tourism; 4 out of 10 tourists choose their destination based on its cultural offering". In addition, "an increase in interest in the past and, therefore, in the awareness of historic and artistic heritage has also taken place. This dynamic has been clearly reflected in a rise in cultural activities in recent decades and social longing for culture and heritage" (UNWTO 2015b: 36). Estimates suggest that approximately $85 \%$ of the general population can be considered current or potential heritage tourists (Timothy 2011: 41). This means that many locations are now actively developing their tangible and intangible cultural assets so as to gain a competitive advantage and to generate a sense of local uniqueness worth visiting. The existing data on heritage tourism is almost always based on estimates since there are many misunderstandings and missing statistical data on cultural and heritage tourism, mainly because it is difficult to define and measure it. One of the main reasons is a lack of conceptual clarity as regards defining who is a heritage/cultural tourist and what constitutes heritage tourism (Timothy 2011:22). Nevertheless, since practically every tourist trip in- 
volves an interaction with local culture, when paired with growing trends towards tourism in general, a high percentage of heritage tourism shares is a likely outcome.

According to Timothy, heritage tourism encompasses a multitude of motives, resources and experiences, and is different for every individual and place visited (2011: 4). In a broader sense, heritage is "what we inherited from the past and use in the present day" (Timothy 2011:3), which includes both natural and cultural heritage (tangible and intangible elements) shared and experienced by all of us. Heritage becomes heritage only when we, and we alone, give it a value-laden significance in anthropogenic terms - its meaning. In other words, tourists go to view not just artefacts, but psychological artefacts, their meanings as created in the minds of each and every one of us (Boniface and Fowler 1993: 158).

There are four levels or scales of heritage tourism experience linked by the notion of shared heritage (Timothy and Boyd 2003: 14): world, national, local and personal. World heritage attractions draw large masses of tourists from many countries and they present the most popular tourist destinations. Today, more than 1,000 of natural and cultural heritage sites are inscribed on the World Heritage List and more than 400 of them are inscribed on the List of Intangible Cultural Heritage. ${ }^{1}$ National level attractions and sites are associated with the development of nation-states and they symbolise national unity and patriotism. They are extremely important to domestic visitors, but they may also attract the attention of international tourists. Most heritage sites in the world are local in their extent, and they stir emotions within the community or region, and contribute to a local heritage experience. Personal heritage, on the other hand, is the most basic level and the most meaningful aspect for each individual personally. It encompasses places, events and people directly involved in one's own inherited legacy (Timothy 2011). All four scales of heritage tourism experience - the global/national/local/personal - are interchangeable and overlap. Even if this occurs at the same location, a particular heritage experience for one person may differ from what it is for another (Timothy and Boyd 2003), or as Boniface and Fowler put it "the same thing can mean different things to different peoples" (1993: 149).

\section{Creativity and tourism}

The word creative has now continued to increase in popularity for more than a decade. Everything and anything has received the prefix creative; from creative industries, creative classes, creative economy, creative cities, creative business, creative governance to creative tourism (Jelinčić and Žuvela 2012: 78). The buzz surrounding this word has continued for quite a while given that we live in fast-paced times, in which technologies and market ideology have imposed rapid changes and shifts from one trend to another.

\footnotetext{
${ }^{1}$ World Heritage List: http://whc.unesco.org/en/list (accessed 23. 2. 2017); List of Intangible Cultural Heritage: http://www.unesco.org/culture/ich/en/lists (accessed 23. 2. 2017).
} 
The role creativity plays in the formation of a city, nation, or organization is not an entirely novel phenomenon or practice, but with the decline of physical constraints on cities and communities in recent decades, creativity has become the principal driving force in the growth and development of cities, regions and nations (Florida 2005: 1). Many cities began using culture as a basic resource for brand creation in order to, eventually, stimulate tourist visits and consumption, among other things. Thus, a cultural turn has been noted whereby the perception of the cultural sector as a budgetary cost has changed into a driving force for economic regeneration. The cultural/creative industries proliferated as drivers of urban development stimulating cultural entrepreneurship, city branding, urban regeneration, innovations and the development of tourism.

Many cities have introduced cultural/creative industries in their development policies proving them worthwhile, such as Amsterdam, Barcelona, Berlin, Birmingham, Newcastle, Gateshead, Oslo, Stockholm, Vilnius, etc. Furthermore, some city districts have proven that their investment in cultural urban regeneration has paid off. Examples include London's East End; Helsinki’s Aranbianranta; the Subtopia micro cluster in Stockholm's district of Botkyrka; the Warsaw Praga Poludnie; Poblenou in Barcelona, etc. Some of these projects had success with branding based on the cultural/creative industries: Newcastle used its musical celebrities (The Animals, Brian Johnson from AC/DC, Neil Tennant from Pet Shop Boys, Bryan Ferry); Copenhagen focused on Hans Christian Andersen and the Little Mermaid; Liverpool used the popularity of the Beatles; while the UK focused on a number of cultural industries' brands from Daniel Craig, J. K. Rowling, David Bowie, Kate Moss, Alexander McQueen, Jamie Oliver to Zaha Hadid and Anish Kapoor. Helsinki used its architect and designer Alvar Aalto (Jelinčić, Žuvela and Polić 2012: 11).

On the one hand, cultural/creative industries prove to be extremely successful as regards urban regeneration, while on the other hand, estimates show that cultural heritage is the dominant tourist attractor of all cultural assets. Can these be reconciled in order to increase success? Culture definitely plays an important role in distinguishing places from one another, but many places adopt similar strategies (often copying or borrowing ideas from others), and therefore even culture begins to lack distinction. Every town, city, region, nation has its own heritage, but this does not necessarily mean that they are appropriate or attractive for tourism. In fact, many places all started to look similar; churches, castles and museums offer (almost) the same cultural elements to visitors. In the $21^{\text {st }}$ century, creativity has become an important aspect of development strategies and of tourism development, stimulating the creation of more distinctive and creative heritage attractions (Richards and Wilson 2007: 3). The cultural/creative industries proved in particular to be an excellent tool in creating stories which have distinctive features in competition with other cultural assets. Since they are expressions of contemporary, and what is often also popular culture, consumers easily identify with them. This enables easier consumer immersion without their possessing a greater cultural knowledge. In addition, heritage is old and it is not always easy for a consumer to make associations with previous historical periods (s)he did not live in. Thus, the symbiosis of the cultural/creative 
industries (such as music, design, video-games, film, etc.) and heritage enables an immediate identification with stories about that heritage.

This is especially visible in the Swedish approach to the cultural/creative industries which uses the term experience industry instead of cultural/creative industries. "The purpose of using experience was to place the focus on the consumer and not the producer. Since experiences are unique to each individual person, focus should be placed on how experience will be perceived... The experience industry..., is primarily about positive, memorable experiences" (Nielsén 2004: 8). Therefore, if the focus is on the consumer, it is highly likely that (s)he will more easily identify with modern representations of heritage which use the cultural/creative industries as its tools.

In parallel with the cultural/creative industries boom and the mentioned rise of cultural tourism, research reveals that "a new profile of tourist-seeking experiences focused on relaxation, discovery, enjoyment, and knowledge" (UNWTO 2015b: 35 ) has been noted, and cultural tourism is a natural ally to such experiences.

However, cultural tourism as a mere sight-seeing activity is not enough. Additionally, a need for more engaging tourist activities has been noted, which would enable a tourist to have a real experience of the destination (s)he is visiting. Thus, creative tourism has proliferated as well as different types of participatory tourist activities. Creative tourism was first defined as a type of tourism which "offers visitors the opportunity to develop their creative potential through active participation in courses, and learning experiences that are characteristic for the holiday destination where they are undertaken" (Richards and Raymond 2000). As in the case of the cultural/creative industries, creative tourism involves visitors in concrete activities which enable an easier identification and immersion in local cultures, thus leaving greater impressions of the destination.

Today, there is a number of tourist activities in practice which are labelled as creative although they are far from the original concept of creativity involving the creation of something new; thus, a number of tourism activities focusing on simple labour supply (such as olive or grape picking) is often categorised as creative tourism. Rather than entering into a detailed discussion of the intensity of the creativity in such tourist activities, de Bruin and Jelinčić propose a new concept which can embrace different tourist activities labelled as "creative": participatory experience tourism or PET which involves "a process of adding value to an experience through active participation by the tourist" (2016:60). This overarching concept thus embraces a series of experiential activities which, in this case, may but are not necessarily creative in nature. In line with creative tourism, PET activities are equally important for the creation of the destination image as well as for visitor satisfaction, since they also offer direct immersion in local cultures, also eventually provoking an emotional affection for the product/service or the destination.

\section{The experience economy and tourism}

Experiences directly relate to destination images as well as to visitor satisfaction. In order to avoid negative experiences and to enhance the destination image, experi- 
ence management can be applied. This is the subject of the experience economy. It is not a novel concept; it was first coined in 1971 by Alvin Toffler in his book Future Shock, who talked about the experiential industry, experience makers and even psycheservice industries and psych-corps in order to predict the form of the future economy, which would depend on the "design of new goods and the process of coating them with stronger, brighter, more emotion-packed psychological connotations" (1970: 233). At that time, the concept of the experience economy was used in the context of future predictions regarding the development of the economy. The term was revived twelve years later by Holbrook and Hirschman (1982), only on this occasion as our reality: consumption experiences were viewed as a phenomenon directed toward the pursuit of fantasies, feelings, and fun. Thus, although the experience economy may not have been defined in the same way as we see it today, a clear connection between emotional experiences and products/services was detected.

Today, many different definitions of the term experience economy exist. Rather than trying to provide an authoritative definition of it, it is simply explained as encompassing "economic activities related to peoples' experiences" (Sundbo and Sørensen 2013: 1). Such an economy stresses the impact which products/services can have on peoples' lives but, at the same time, studies ways of effective and/or increased consumption of products/services by creating experiences around them. While the economy previously focused on tangible satisfaction, the experience economy offers psychological satisfaction.

While experiences are inherent to the entertainment industry (film, music, theatre, etc.), they are currently finding fertile soil in a plethora of new genres such as audio-visual media, games, toys, shows, software, multimedia, simulators, virtual reality, etc. They are thus a tool for the successful entertainment and edutainment ${ }^{2}$ businesses. Today therefore, "the concept of selling an entertainment experience is taking root in businesses far removed from theaters and amusement parks" (Pine and Gilmore 1998: 99).

The focus on psychological satisfaction often entails staging experiences to leave a memorable impression. At present, the experience economy finds a close ally in the tourism industry, through the supply of meaningful, often individualised events which engage tourists in memorable ways. Due to an ever-growing need for destination diversification, experiences have become the main tool in creating a tourism supply since tourists can identify with the destination through real-life experience. Consequently, experiences are felt to be both personal sources of information and stories regarding the real identities of the communities with whom they are in contact. This view implies the importance of individual satisfaction with a certain product/service, or the overall tourist destination. A positive experience produces a positive image, and results in a satisfied visitor.

Experiences occur spontaneously, every day, in the tourist-host relationship as well as in the tourist-space relationship which is sometimes difficult to control. However, they can also be created and thus decrease the chances to a minimum of

\footnotetext{
${ }^{2}$ This refers to educational content which is at the same time entertaining.
} 
possible negative images of destinations circulating. Experiences are, therefore, tools that are used to create visitor (dis)satisfaction, or processes used in the creation of what tourists think and feel about the destination. They are the link between a destination and its potential/existing visitors. According to Pine and Gilmore (1998: 30) there are four realms of experience: esthetic, entertainment, education and escape. They are specified according to the variety of consumer connection (absorption, immersion) and the form of participation (active or passive participation) of the consumer in the experience.

Such processes include the creation of different, diverse, innovative, spectacular and sense-engaging products/services which all impact both on visitor satisfaction and the destination image. Prerequisites for success, according to Pine and Gilmore, encompass five main experience design principles: 1) attributing a theme to each experience, 2) harmonising impressions with positive cues, 3) eliminating negative ones, 4) supplying memorabilia as additional experience enhancers, and 5) engaging all five senses in experience creation (1998: 102-105). Theming the experience is important since it allows for an easier identification of a consumer with the subject. When the theme is well defined, the experience is practically staged and consumers can organise their impressions around it with more ease. In other words, they have clear associations with the product/service/destination and know what to expect (e.g. in the case of Hard Rock Café). This is why one effective theme should be "concise and compelling" (Pine and Gilmore 1998: 103), and is the foundation for creating experiences around it. A positive atmosphere always adds to the experience and it is more likely that the consumer will feel good about the experience, thus enhancing the prospect of repeated visits which is especially important for the tourism industry. Thus, positive impressions are depending on the text/visual representations used in marketing or on the site itself as well as colours, scents, flavours, sounds, or even tactile sensations. There is a direct link between the creation of positive cues and engaging all five senses when staging experiences. Engaging senses creates the conditions to stir emotions which have the power to engage consumers in feeling a certain way. If they feel good about the experience, it is highly likely that the positive cues have been appropriately designed. There is no need to further explain that negative cues should be avoided. However, there might be experiences which, in order to be effective, ought to generate fear, anger or sorrow for example (e.g. in staging a simulation of an earthquake, fire, or volcano eruption). An average consumer would consider them to be "negative" emotions; ${ }^{3}$ yet such experiences which require customers to feel them, are actually considered to be positive and not negative cues. Therefore, a well-staged experience in this case requires the stimulation of "negative" emotions which can be categorized as positive cues. Finally, in order to enhance the experience, it is recommended that the venue supply memorabilia merchandise. Not only does such merchandise increases profits; it also creates memories and thus extends the experience over a longer period than the actual moment in which the

\footnotetext{
${ }^{3}$ Although from a psychological point of view they are not negative, they are rather simply emotions which are sometimes needed for a balanced life.
} 
experience took place. An experience may, therefore, be considered successful if it manages to bring to the fore its three main elements in its consumers: identification with the product/service/destination, emotions and memories.

The mentioned principles do not guarantee success, since a number of other business aspects have to comply with those experiences; still, the experiences are far more engaging for the consumer than the mere products/services. Or as Pine and Gilmore put it, "commodities are fungible, goods tangible, services intangible, and experiences memorable" (1998: 98).

In order to reinforce Pine and Gilmore's theory, similarities in experience creation have been drawn from Freeman Tilden's heritage interpretation principles: 1) interpretation of the exhibit should relate to something within the personality and life experiences of the visitor; 2 ) interpretation is revelation based on information; 3 ) interpretation is an art; 4) the objective of interpretation is not instruction but provocation; 5) interpretation should be holistic; 6) interpretation requires a different approach towards different visitors (Timothy and Boyd 2003: 206-207). Although they are specifically designed for the interpretation of heritage, they coincide with Pine and Gilmore's business principles. Thus, once again, the personal identification of a visitor with the heritage being considered is stressed as well as the need to actively involve her/him in the story about the object of interpretation ("revelation", "provocation").

Similarly, the so called UNIQUE-experience is advocated by Frans Schouten, whereas the word is made of first letters which stand for the following: Uncommon, Novelty, Quality, Understanding, and Emotions (2002: 24). Although some new elements are introduced (such as "uncommon" and "novelty" which are needed for acquiring distinctive features from other heritage assets), they also stress the importance of identification ("understanding", "quality") and emotions.

\section{Personal, local and world heritage: case studies}

In recent years, more attention has been paid to delivering unique, creative and memorable tourist experiences to potential visitors of heritage attractions in order to increase competitiveness. Museums constitute some of the most visited tourist attractions in the world (Timothy 2011). New developments in museum practice expect museums not only to preserve and conserve heritage, but also to exhibit in an innovative and creative way, focusing on the consumer and experience creation.

This is why three Croatian museums have been chosen as case studies for the analysis in this paper, as to see how they make use of Pine and Gilmore's experience design principles. All three of them are considered successful in terms of their experiential heritage interpretation and consequently also in tourist terms, as proven by the awards they have received. These are the Museum of Broken Relationships, the Batana Eco-Museum and the Krapina Neanderthal Museum. Apart from their 
reputation as examples of best practices, the case studies have also been chosen for analysis due to the differences between them in the scale of heritage they represent (personal, local, world heritage ${ }^{4}$ ), as based on Timothy and Boyd's criteria which is independent from the criterion relating to their success. The characteristics upon which the above mentioned museums have been chosen to present successful case studies are the following:

\section{Museum of Broken Relationships}

(i) it represents personal heritage (it is based on personal stories we all share and with which everyone could identify);

(ii) uniqueness (it received the award for Europe's most innovative museum in 2011);

(iii) public participation in contributing to the permanent collection with donated items - the public as a co-creator in experience creation;

(iv) it is at the top of the list of recommended museums to visit in Zagreb (TripAdvisor 2017).

\section{Batana Eco-Museum}

(i) it is the first eco-museum in Croatia (a community oriented museum representing local heritage);

(ii) since 2016 it has been on the UNESCO register of best practices in preserving the intangible and cultural heritage of the world;

(iii) in 2007 the museum project received the award of best tourist product in the Adriatic.

The Krapina Neanderthal Museum

(i) it is a unique complex for visitors (the Krapina Neanderthal Museum is located near the world famous site of the Krapina Neanderthals - "Hušnjakovo");

(ii) at this archeological site, the world's largest and richest collection of Neanderthal fossil remains in Croatia and Europe were found; the site represents local (it is listed as one of the richest Paleolithic habitats of Neanderthals in Croatia), regional (Krapina Neanderthal site has been awarded the label of being European Heritage) and world heritage (the site played an important role in the historical development of paleoanthropology and it represents the history of our human civilization);

(iii) the museum received numerous prizes for its contribution to the promotion of the findings of the Krapina Neanderthal "Hušnjakovo" and for making a significant contribution to the promotion of culture and tourism in the town of Krapina, Krapina-Zagorje County both in Croatia and abroad (receiving the

\footnotetext{
${ }^{4}$ The concept of "world heritage" is somewhat ambiguous: on the one hand world heritage sites are associated with the UNESCO World Heritage List; on the other hand, some of them may fulfil the criterion of world heritage as defined by Timothy and Boyd, while not being on the UNESCO WH List. In the case of the Krapina Neanderthal Museum, we have referred to its world features associated with its history of human civilization, although it is not listed by UNESCO. Thus, further research could be done on the notion of "world heritage", which falls out of the scope of this paper.
} 
Charter of the Town of Krapina, Krapina-Zagorje County Plaque, Croatian tourism award "Anton Štifanić").

In order to explore the views, experiences, beliefs and motivations of the museum creators and so as to gain insight into and a deeper understanding of the process of museum experience creation, the preferred methodological approach involved conducting qualitative research using semi-structured interviews as a method of data collection. The research design was based on relevant literature concerning the experience economy - Pine and Gilmore's experience design principles and the 4E experience realms model (esthetic, entertainment, education and escape). The interview questions were semi-structured, which means that they consisted of a predetermined set of open questions with additional questions being asked to clarify or further expand on certain issues relating to the process of museum experience creation. Before conducting the interviews, all interviewees were contacted via telephone and e-mail in order to additionally inform them about the research. Over the period from March 6 to March 9 (2017), museum creators and employees involved in the three selected case studies were interviewed and recorded for later analysis.

\section{Research results}

According to Pine and Gilmore's principles, a well-defined theme is the central component of experience creation which should aim to immerse visitors and make them part of the experience. What characterized all three interviewed Croatian museums was the presence of a coherent and concise theme on which the whole process is based.

The Museum of Broken Relationships is an original, unique and creative art project founded in 2006. It started as a travelling collection of items donated by members of the public. The Museum opened in 2010 as Zagreb's first privately owned museum dedicated to failed romantic relationships. It received the Kenneth Hudson Award for Europe's most innovative museum in 2011, and opened its first franchise in Los Angeles in 2016. The entire museum concept is based on universal experiences of love and loss from people all over the world (personal heritage). It includes a permanent exhibition of donated items and stories, travelling exhibitions and a virtual web museum.

The Batana Eco-Museum is the first eco-museum in Croatia dedicated to the traditional wooden boat from Rovinj known as the batana and to the community which has chosen it as its symbol. The batana reflects the continuity of local tangible and intangible maritime and fishing heritage, as well as the continuity of the everyday life of the local population. The eco-museum with its programmes participates in the development of an authentic cultural offering for all visitors, and creates a bond which connects local residents of various ethnicities (especially Italians and Croats). Based on Timothy and Boyd's criteria, it represents a local heritage experience, and 
also world heritage. The Museum has been awarded recognition on numerous occasions and in 2016 was selected for the UNESCO register of best practices in preserving the intangible cultural heritage of the world. Besides a permanent exhibition of batanas and fishing tools, the project offers various events that ensure a unique experience combining tradition and contemporary life, past and present, and the story of this ancient wooden vessel.

The Krapina Neanderthal Museum is located near the world famous site of the Krapina Neanderthals "Hušnjakovo”. In 1899, the largest number of Neanderthal fossil remains in Europe dating back to 125,000 years BC was found at this site. The site therefore represents local, regional and world heritage. It is protected as the first paleontological natural monument in Croatia, and is listed as one of the richest Paleolithic habitats of Neanderthals in Europe, having played an important role in the historical development of paleoanthropology. Today, the Krapina Neanderthal Museum presents - in an interactive fashion - the origins of life on Earth and the evolution of humankind, using a time machine as a conceptual device to achieve this, with a special emphasis on the Neanderthal period.

Theming the experience is the first important step in the identification of a visitor with the subject. All three interviewed museums focused on different themes representing different scales of heritage (personal, local and world). From the perspective of scale, the research results confirmed an overlapping of personal/local/world heritage in all three cases. The Museum of Broken Relationships, for instance, might be considered first and foremost an important conveyor of personal heritage, yet through personal stories and items the museum also reflects the political, social and cultural context of the cities, states or local communities (local scale). In addition, by collecting, preserving and presenting tangible and intangible personal heritage from all over the world, it deals with universal stories and experiences we all share and may identify with (world scale). The Batana Eco-Museum as a community-oriented museum represents local heritage, but it also preserves and presents, in a much wider sense, the intangible maritime heritage of the world (world scale).

Aside from the importance of having a well-defined museum theme, the interview results illustrated another important aspect for the process of identification with the subject - universality. All three museums highlighted how every museum should have something universal attached to the main story it presents, in order to be successful and to achieve the easier identification and connection of its visitors with the subject. The Museum of Broken Relationships focuses on universal experiences of love and loss connecting different people from all over the world, showing how love and breakups are universal. The Batana Eco-Museum focuses on the larger family of traditional vessels on the Adriatic and Mediterranean, as well as on the maritime heritage and culture of Europe and the world, connecting different people through music, gastronomy and friendship. Finally, the Krapina Neanderthal Museum represents the origin of life on Earth and the evolution of humankind and our civilization.

All other tools and techniques related to the four realms of experience (esthetic, education, entertainment, escape) and as used in museums should complement and 
enhance the previously defined theme as a whole, striving to create positive museum experiences. Every element of the museum exterior, interior, learning processes, interaction with people as well as the inclusion of each visitor in the stories, artworks and environment help generate a vivid experience. The three Croatian case studies and their processes of museum experience creation based on Pine and Gilmore's experience design principles are described in detail in table one.

Another important finding relates to participatory experience (de Bruin and Jelinčić 2016) and local community engagement. Museums provide the possibility of immersing visitors and making them a part of the experience through using different tools and techniques (participatory techniques). The Museum of Broken Relationships exhibits everyday objects submitted by ordinary people who have gone through a breakup or lost a loved one. In this case, the public contributes to the permanent collection, travelling exhibitions and virtual museum, by donating items and actually becoming a co-creator of the experience. In the Batana Eco-Museum, heritage management is placed in the hands of the local community and visitors can actively participate in the local community's activities through various authentic events and programmes. On the other hand, the Krapina Neanderthal Museum with its exterior and interior elements, multimedia presentations, interactive exhibits and other experiential activities contributes to the generation of a participatory experience for visitors, but local community engagement has not been enlisted. The best example of local community involvement concerns the Batana Eco-Museum. In general, eco-museums are community oriented museums and they require the involvement of community members (Timothy 2011). The central focus of heritage management at the Batana Eco-Museum is on the common cultural heritage-based identity of Italians and Croats.

Participatory experience directly links to escapism, which aims to actively engage the visitor in the escapist experience and to stimulate positive emotions through different sensory techniques. It is usually difficult to engage all five senses in a museum experience. All interviewed museums claimed to use a number of sensory techniques in order to stimulate interaction and enliven experiences. These techniques include a wide variety of multimedia presentations, hands-on interactions with artefacts, the presentations of living displays, interactive exhibits, and creative workshops etc., which related to different senses (sight, hearing, touch, smell, and taste). The Batana Eco-Museum was successful in interacting with the full array of senses (see table one). Unlike traditional museums, eco-museums are located in their natural environment, which makes it much easier for them to engage visitors in feeling in a certain way.

The last stage of experience creation is the creation of memories through souvenirs which serve to extend the experience over a longer period. In all three cases, souvenirs were an important part of the museum experience and they were all specially designed for each museum.

A comparative review of the three case studies according to the above analysed criteria is displayed in table one. 


\begin{tabular}{|c|c|c|c|}
\hline 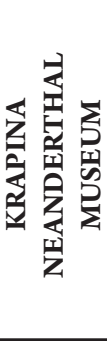 & 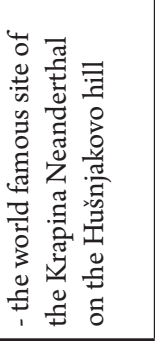 & 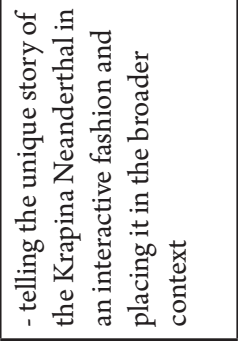 & 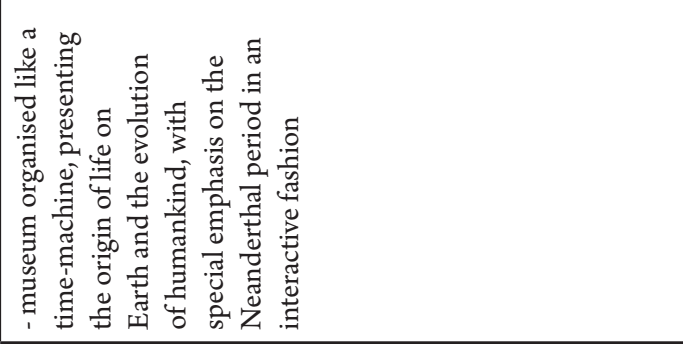 \\
\hline 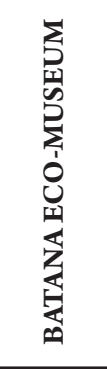 & 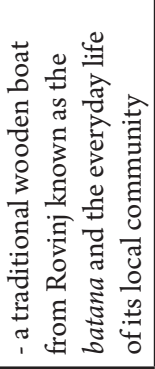 & 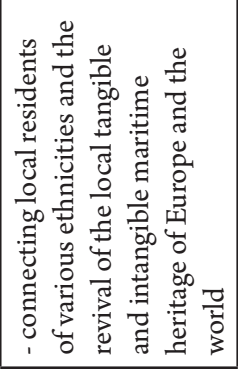 & 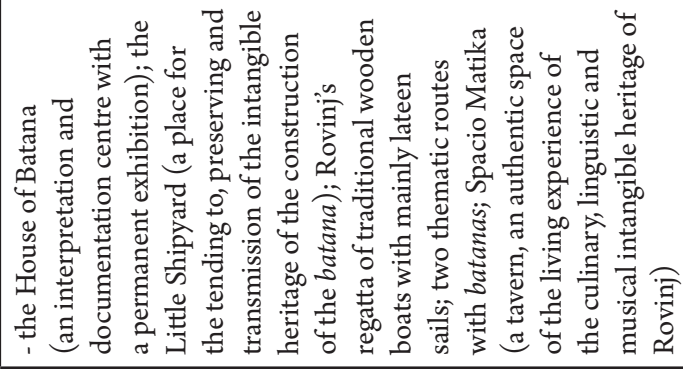 \\
\hline 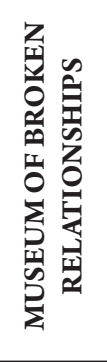 & 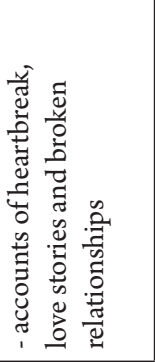 & 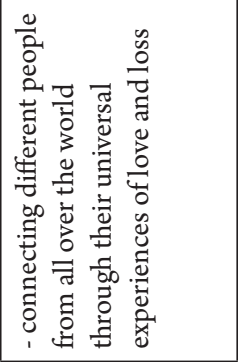 & 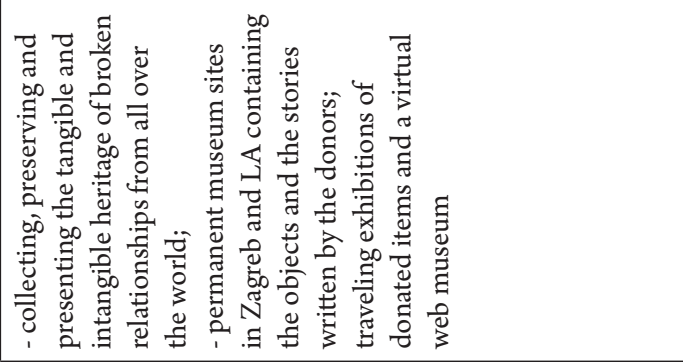 \\
\hline & 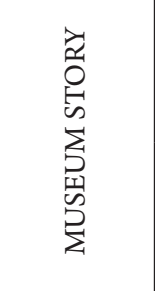 & 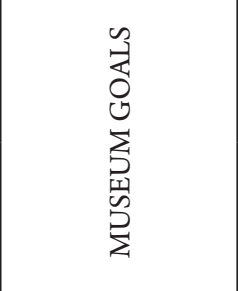 & 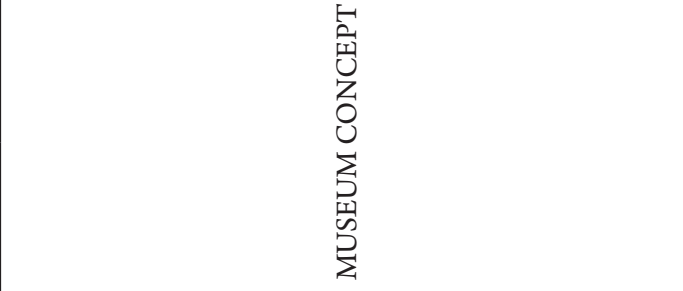 \\
\hline & \multicolumn{3}{|r|}{ 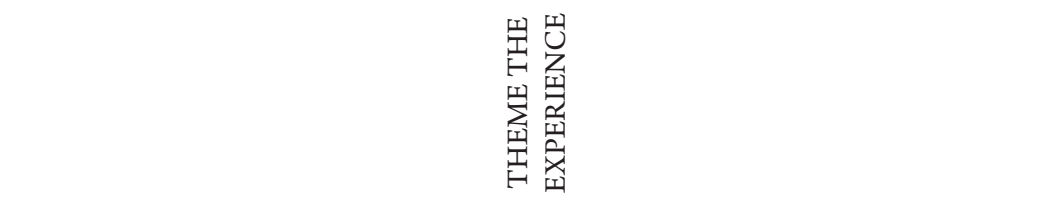 } \\
\hline
\end{tabular}




\begin{tabular}{|c|c|c|c|}
\hline 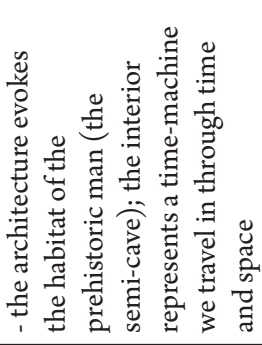 & 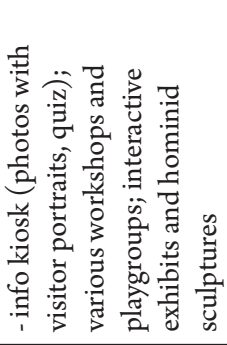 & 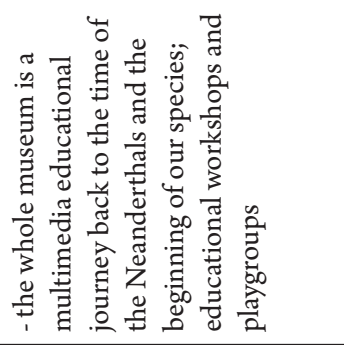 & 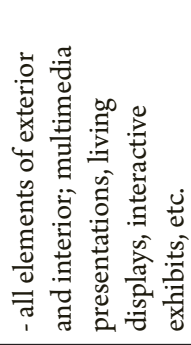 \\
\hline 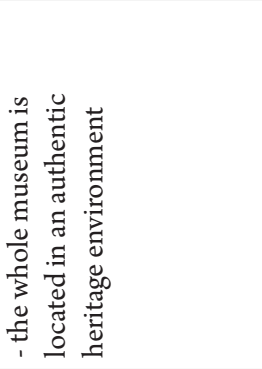 & 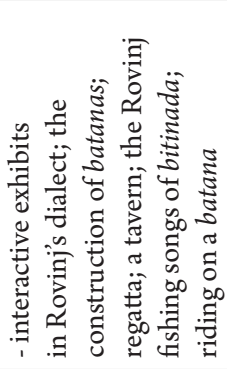 & 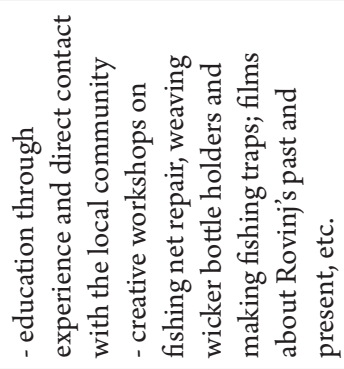 & 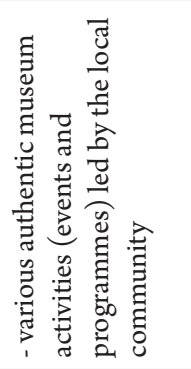 \\
\hline 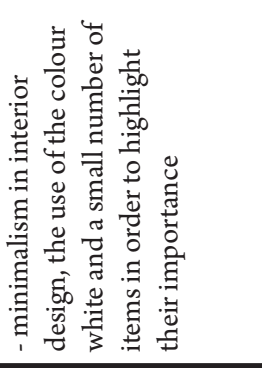 & 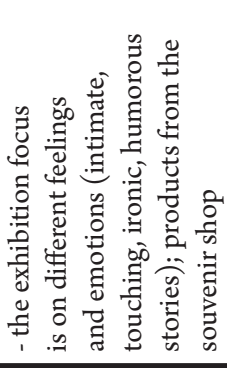 & 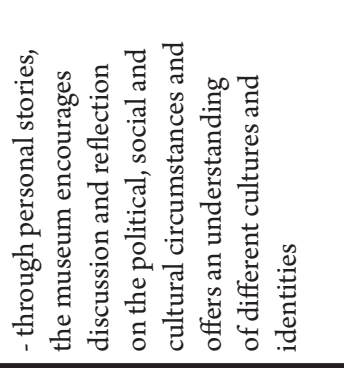 & 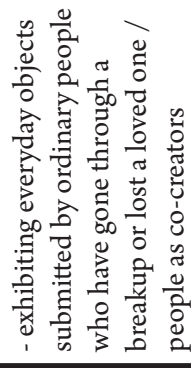 \\
\hline 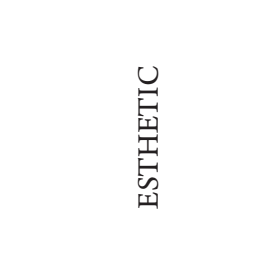 & 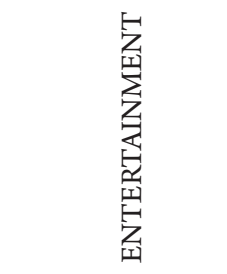 & 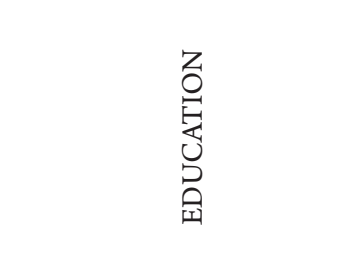 & 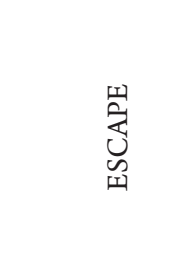 \\
\hline \multicolumn{4}{|c|}{ 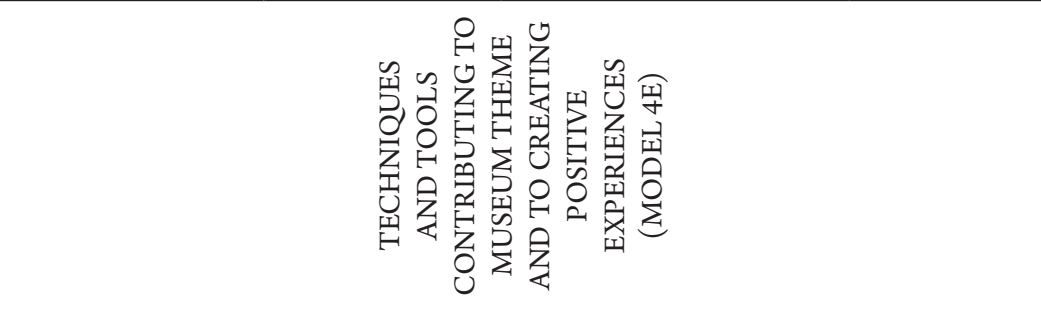 } \\
\hline \multicolumn{4}{|c|}{ 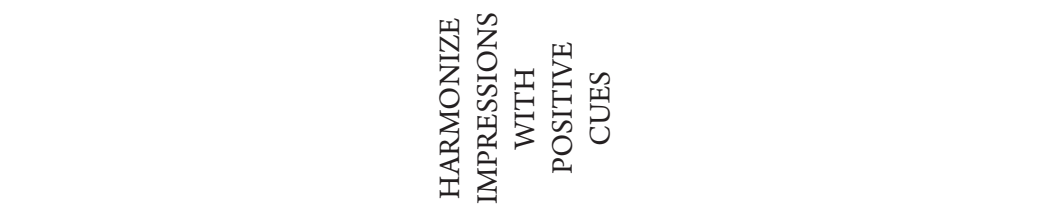 } \\
\hline
\end{tabular}




\begin{tabular}{|c|c|c|c|c|c|c|}
\hline$\underset{\Xi}{0}$ & 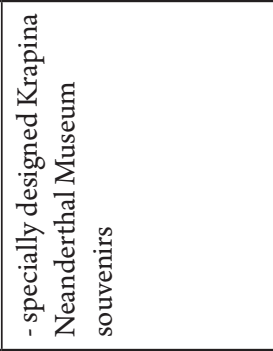 & 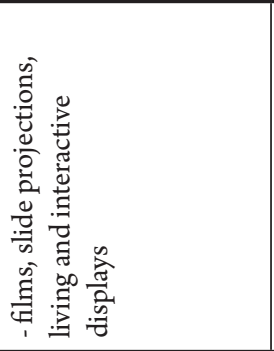 & 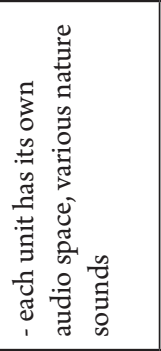 & 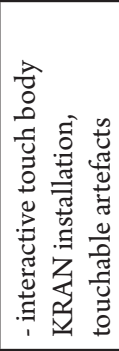 & 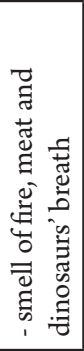 & $\underset{:}{\overparen{0}}$ \\
\hline 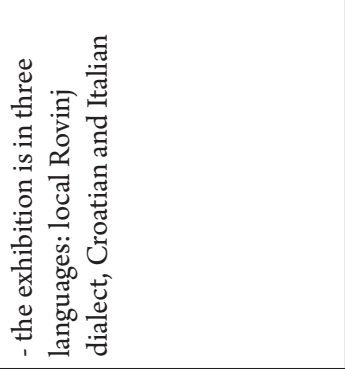 & 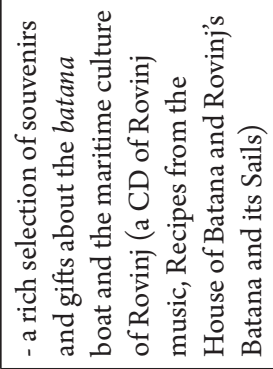 & 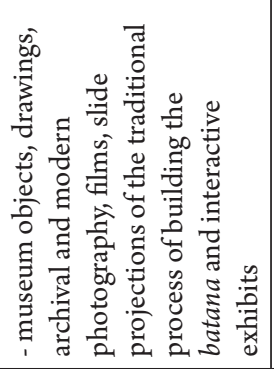 & 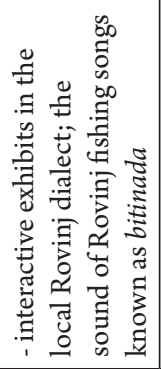 & 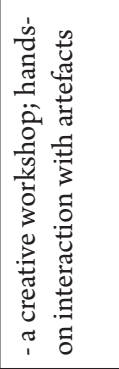 & 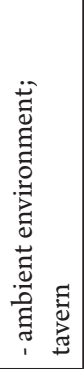 & 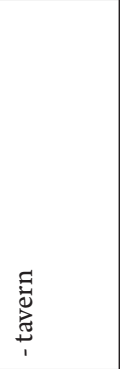 \\
\hline 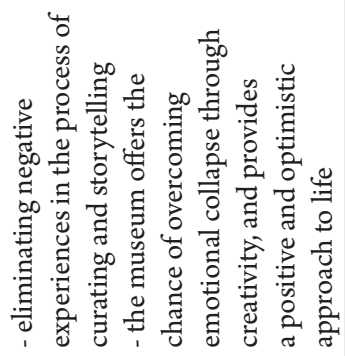 & 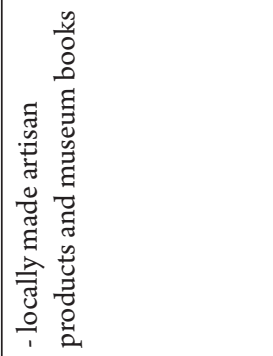 & 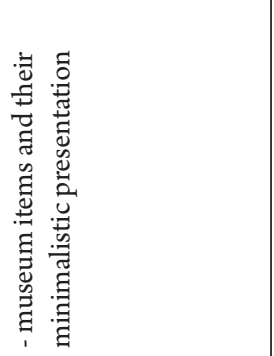 & 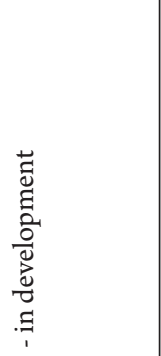 & 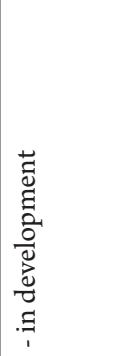 & 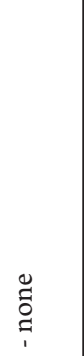 & 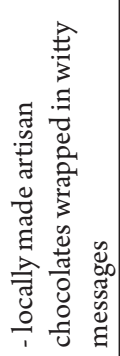 \\
\hline 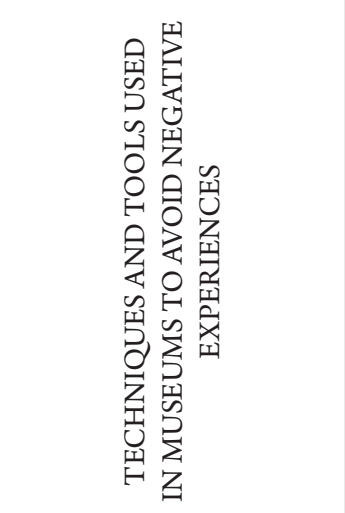 & 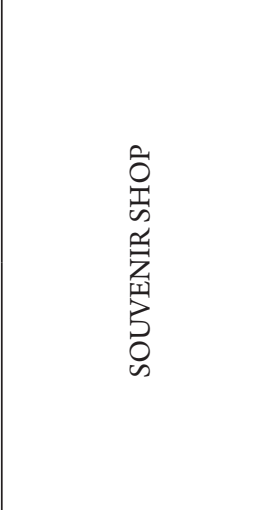 & 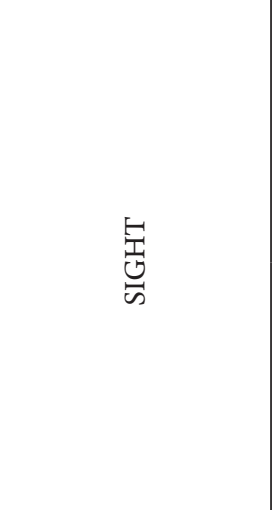 & $\begin{array}{l}\text { 岁 } \\
\text { 至 } \\
\text { 至 }\end{array}$ & 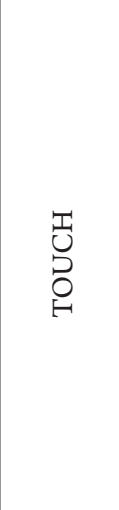 & 帠 & 嵌 \\
\hline 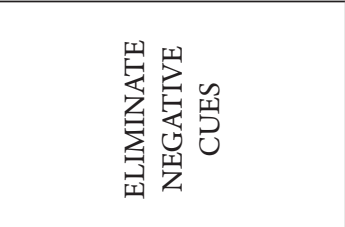 & z规 & \multicolumn{5}{|c|}{ 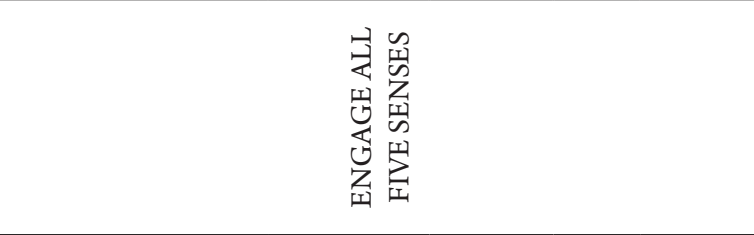 } \\
\hline
\end{tabular}




\section{Conclusions}

On a general level, all three museums can be said to have successfully applied both Pine and Gilmore's experience creation design principles, as well as the four realms of experiences. All of the three analysed case studies were successful in theming the experiences and their universality, so as to be easily identifiable for visitors, as well as in creating themed memorabilia. As concerns the engagement of the visitors' full five senses, the Museum of Broken Relationships was somewhat less successful. The Krapina Neanderthal Museum has somewhat failed in generating a stronger engagement of visitors with the local community so as to achieve a participatory tourist experience. But rather than offering comparisons between the three museums where such methods might not be strictly applicable, we can conclude that the theme itself often dictates the use of experience creation techniques; in some cases, it is possible to include the mentioned techniques, whilst on other occasions it is not. Needless to say, all three museums are representative examples of theoretical experience creation requirements.

An experience is only successful if it enables a visitor to easily identify with the exhibited story, if it excites his or her emotions and if it leaves memorable traces of such an experience. The analysed case studies drew on a number of cultural/creative industries such as architecture, design, film, music, crafts, ICT, and gastronomy in creating both the exterior and the interior of the museum, as well as in the creation of the exhibition(s) and accompanying events. The effect of the cultural/creative industries is enhanced when the range of products/services offered includes creative tourism and participatory experience tourism. The use of these modern tools offers visitors easy immersion in the themes being conveyed, whether they relate, for example, to learning a themed song or trying to prepare a local dish. Having personal experiences and, more importantly, feeling them on an emotional level, offers visitors a personal source of information as regards the community under consideration. This not only creates an image of the museum itself but also of the destination as a whole, thus leaving greater impressions and potentially provoking a positive image of the larger area.

Personal experiences, furthermore, enable a visitor to assess the value of the presented heritage, giving it a meaning that it carries not only for locals but also for the visitors themselves. Since experiences are individual and indeed unique to each individual, a successful museum presentation should focus on the perception of the experience it offers. Nevertheless, in order to please the visitor, museums should not move away from authentic representations of the heritage they display; moreover, visitors should be encouraged to actively participate in the co-creation of museum and/or local experiences since they generate more powerful connections and a greater understanding of heritage which eventually increases the probability of meaningful memories forming of the attraction and the destination. 


\section{REFERENCES}

Boniface, Priscilla and Peter Fowler. 1993. Heritage and Tourism in "the Global Village". London: Routledge.

De Bruin, Anne and Daniela Angelina Jelinčić. 2016. "Toward Extending Creative Tourism. Participatory Experience Tourism”. Tourism Review 71/1: 57-66. [https://doi.org/10.1108/TR-05-2015-0018]

European Commission. 2017. "Cultural Tourism”. https://ec.europa.eu/growth/sectors/tourism/offer/cultural_en (accessed 17.2.2017).

Florida, Richard. 2005. Cities and the Creative Class. New York: Routledge.

Fredrickson, Barbara Lee. 2000. "Extracting Meaning from Past Affective Experiences. The Importance of Peaks, Ends and Specific Emotions”. Cognition and Emotion 14: 577-606. [https://doi.org/10.1080/026999300402808]

Holbrook, Morris B. and Elizabeth C. Hirschman. 1982. “The Experiential Aspects of Consumption. Consumer Fantasies, Feelings, and Fun”. Journal of Consumer Research 9/2: 132-140. [https://doi.org/10.1086/208906]

Holyfield, Lori. 1999. "Manufacturing Adventure. The Buying and Selling of Emotions". Journal of Contemporary Ethnography 28: 3-32. [https://doi.org/10.1177/089124199129023352]

Jelinčić, Daniela Angelina and Ana Žuvela. 2012. "Facing the Challenge? Creative Tourism in Croatia”. Journal of Tourism Consumption and Practice 4/2: 78-90.

Jelinčić, Daniela Angelina, Ana Žuvela and Marijo Polić. 2012. Zagreb kao kulturni proizvod. Akcijski plan poticanja razvoja kulturnih/kreativnih industrija u gradu Zagrebu. Zagreb: Institut za međunarodne odnose.

Jelinčić, Daniela Angelina. 2017. "Kreiranje i br\&iranje doživljaja u kulturi i kulturnom turizmu”. Suvremena trgovina 42/2: 14-16.

Nielsén, Tobias. 2004. Understanding the Experience Industry. A Swedish Perspective on Creativity. Gothenburg: QNB Analys \& Kommunikation AB.

Pine, B. Joseph II and James H. Gilmore. 1998. "Welcome to the Experience Economy”. Harvard Business Review July-August: 97-105.

Richards, Greg and Crispin Raymond. 2000. “Creative tourism”. ATLAS News 23: 16-20.

Richards, Greg and Julie Wilson. 2007. Tourism, Creativity and Development. London, New York: Routledge.

Schouten, Frans. 2002. "Effective Communication with Visitors at Heritage Sites". In Culture: A Driving Force for Urban Tourism - Application of Experiences to Countries in Transition. Daniela Angelina Jelinčić, ed. Zagreb: Institute for International Relations, 21-26.

Sundbo, Jon and Flemming Sørensen. 2013. "Introduction to the Experience Economy”. In Handbook on the Experience Economy. Jon Sundbo and Flemming Sørensen, eds. Cheltenham, Northampton: Edward Elgar, 1-17. [https://doi.org/10.4337/9781781004227.00005]

Timothy, Dallen J. and Stephen W. Boyd. 2003. Heritage Tourism. Essex: Prentice Hall, Pearson Education Ltd.

Timothy, Dallen J. 2011. Cultural Heritage and Tourism. An Introduction. Bristol, Tonawanda, North York: Channel View Publications.

Toffler, Alvin. 1970. Future Shock. New York: Random House.

TripAdvisor. 2017. "Things to do in Zagreb". https://www.tripadvisor.com/Attractions-g294454-ActivitiesZagreb_Central_Croatia.html (accessed 16.3.2017).

UNWTO. 2015a. Tourism Highlights. https://www.e-unwto.org/doi/pdf/10.18111/9789284416899 (accessed 16. 3. 2017).

UNWTO. 2015b. Affiliate Members Global Reports, Volume twelve - Cultural Routes and Itineraries. Madrid: UNWTO.

UNWTO. 2016. Tourism Highlights. https://www.e-unwto.org/doi/pdf/10.18111/9789284418145 (accessed 16. 3. 2017).

http://whc.unesco.org/en/list (accessed 23. 2. 2017).

http://www.unesco.org/culture/ich/en/lists (accessed 23. 2. 2017). 


\section{Stvaranje doživljaja u turizmu baštine. Snaga osjetila}

Rad raspravlja o uvjetima potrebnim za stvaranje smislenih i nezaboravnih doživljaja u turizmu te za povećanje konkurentnosti projekata turizma baštine. Cilj rada je istražiti primjenjuju li tri studije slučaja (Muzej prekinutih veza, Zagreb; Muzej krapinskih neandertalaca; Ekomuzej batana, Rovinj) teorijska načela stvaranja doživljaja (načela Pinea i Gilmorea, Timothyja i Boyda, Tildena i Schoutena), a oslanjajući se na recentni razvoj kreativnog turizma te uporabu kulturnih/kreativnih industrija. Načela ekonomije doživljaja stavljaju se u odnos s turizmom baštine kako bi se dokazao uspjeh njihove uporabe u suvremenoj prezentaciji baštine.

Ključne riječi: turizam baštine, kreativni turizam, kulturne/kreativne industrije, stvaranje doživljaja, nezaboravna iskustva, Hrvatska 